\title{
Phytochemical and Biological Investigations on Cephalaria anatolica
}

\author{
Gaye Sumer, Nazli Boke Sarikahya and Suheyla Kirmizigul ${ }^{*}$ \\ Department of Chemistry, Faculty of Science, Ege University, 35100, Bornova, Izmir, Türkiye
}

(Received March 13, 2017; Revised June 07, 2017; Accepted June 08, 2017)

\begin{abstract}
The aerial parts of Cephalaria anatolica yielded two previously undescribed hederagenin-type triterpene glycosides, namely cephosides B (1) and C (2), in addition to eleven known natural compounds. The new compounds were identified as 3-O- $\beta$-D-glucopyranosyl-(1 $\rightarrow 3$ )- $\beta$-D-glucopyranosyl-(1 $\rightarrow 3)-\alpha$-Lrhamnopyranosyl-(1 $\rightarrow$ 2)- $\alpha$-L-arabinopyranosyl hederagenin 28 - $O$ - $\beta$-D-galactopyranosyl-( $1 \quad \rightarrow \quad 6)-\beta$-Dglucopyranosyl ester (1) and 3-O- $\alpha$-L-rhamnopyranosyl-(1 $\rightarrow 4$ )- $\beta$-D-glucopyranosyl-( $\left.\begin{array}{lll}1 & \rightarrow & 3\end{array}\right)$ - $\alpha$-Lrhamnopyranosyl-(1 $\rightarrow \quad 2)$ - $\alpha$-L-arabinopyranosyl hederagenin 28 - $O$ - $\beta$-D-galactopyranosyl-( $1 \quad \rightarrow \quad 6)-\beta$-Dglucopyranosyl ester (2) by 1D and 2D NMR spectroscopic data, HRESIMS analysis and chemical evidence. The two new triterpenoid saponins and the $n$-butanol extract were evaluated for their hemolytic activity in human erythrocyte cells and immunomodulatory properties in activated whole blood cells by PMA plus ionomycin. While only $n$-butanol extract increased IL- $1 \beta$ concentration strongly with a value of $760.52 \mathrm{pg} / \mathrm{mL}$, cephoside C and $n$-butanol extract augmented a slight IFN- $\gamma$ secretion with values of 4874.11 and $4750.20 \mathrm{pg} / \mathrm{mL}$, respectively. None of the compounds changed IL-2 levels significantly and showed hemolytic activity.
\end{abstract}

Keywords: Cephalaria anatolica; Caprifoliacea; cephosides B-C; hemolytic activity; immunomodulatory activity. (C) 2017 ACG Publications. All rights reserved.

\section{Introduction}

The genus Cephalaria (Caprifoliacea) comprises about 94 species distributed mainly in the Mediterranean Region and the Middle East. In Turkey there are 40 taxa and 24 of them are endemic [1, 2]. Humans have used Cephalaria genus for many purposes such as dyeing material for the wool, an additive in bread, a traditional medicine to cure rheumatism, lung and cardiac diseases and regulate menstruation [3, 4]. This wide range of usages has led to investigations on different Cephalaria species. Many chemical identification studies have been reported that this genus contains triterpenoid saponins, flavonoids, alkaloids, furofuranic lignans and iridoids [5-13]. According to these literatures, it is also known that these compounds have different activities including antimicrobial, hemolytic, hypolipidemic, immunomodulating and cytotoxic [7-8, 11-12, 14].

In the light of these literature data, phytochemical and activity studies were carried out on $n$ butanol extract of Cephalaria anatolica which is an endemic species to Turkey. Herein we reported totally 13 triterpene glycosides, isolated from $C$. anatolica and two of them are new, named cephosides $\mathrm{B}-\mathrm{C}(\mathbf{1 - 2})$. The structures of the new triterpene glycosides were determined as $3-O-\beta$-D-glucopyranosyl-

*Corresponding author. E-mail: suheyla.kirmizigul@ege.edu.tr

The article was published by ACG Publications www.acgpubs.org/RNP @ Published 07/07/2017 EISSN:1307-6167

DOI: http://doi.org/10.25135/rnp.64.17.03.056 
(1 $\rightarrow$ 3)- $\beta$-D-glucopyranosyl-(1 $\rightarrow 3)$ - $\alpha$-L-rhamnopyranosyl-(1 $\rightarrow 2)$ - $\alpha$-L-arabinopyranosyl hederagenin 28 - $O$ - $\beta$-D-galactopyranosyl- $(1 \rightarrow 6)-\beta$-D-glucopyranosyl ester $(\mathbf{1})$ and $3-O$ - $\alpha$-L-rhamnopyranosyl-( $1 \rightarrow$ 4)- $\beta$-D-glucopyranosyl-( $1 \rightarrow 3$ )- $\alpha$-L-rhamnopyranosyl-( $(\rightarrow 2)$ - $\alpha$-L-arabinopyranosyl hederagenin 28 $O-\beta$-D-galactopyranosyl-( $1 \rightarrow 6)-\beta$-D-glucopyranosyl ester $(2)$. The known compounds were identified as davisianoside A (3), davisianoside B (4) [15], elmalienoside A (5), elmalienoside B (6) [8], macranthoside A (7) [16], macranthodin A (8), macranthodin B (9) [17], akebia saponin D (10), dipsacoside $\quad \mathrm{B} \quad(\mathbf{1 1}) \quad[18], \quad 3-\mathrm{O}-\beta$-D-glucopyranosyl-(1 $\rightarrow 3)-\alpha$-L-rhamnopyranosyl-( $1 \rightarrow 2)-\alpha$-Larabinopyranosyl hederagenin 28-O- $\beta$-D-glycopyranosyl ester (12) [19] and aristatoside A (13) [10]. The structures of these compounds were identified by chemical methods including acidic and alkaline hydrolysis, silylation and extensive spectroscopic analysis, along with 1D, 2D NMR and HRESIMS data. The two new triterpenoid saponins and the $n$-butanol extract were evaluated for their hemolytic activity in human erythrocyte cells and immunomodulatory properties in activated whole blood cells by PMA plus ionomycin.

\section{Materials and Methods}

\subsection{General}

Optical rotations of pure compounds were measured at $23{ }^{\circ} \mathrm{C}$ using Rudolp Research Analytical Autopol I automatic polarimeter fitted with a sodium lamp with $1 \mathrm{~mL}$ cell. IR spectra were obtained on an ATI Mattson Genesis Series Fourier transform infrared spectrophotometer. NMR experiments were performed on Varian AS $400 \mathrm{MHz}$ and Varian ASP $600 \mathrm{MHz}$ instruments in DMSO- $d_{6}$. All chemical shifts were given in ppm units with reference to tetramethylsilane (TMS) as an internal standard and the coupling constant $(J)$ were in Hz. HRESIMS analyses were carried out using a Bruker LC micro-Q-TOF instrument. Medium pressure liquid chromatography (MPLC) was run using a Buchi system (Buchi C605 pumps, coupled to a UV detector) with Buchi glass column (26/920). Lichroprep RP-18 (25-40 $\mu \mathrm{m}$; Merck) and silica gel 60 (0.063-0.200 mm; Merck) were used both for open column chromatography (CC) and MPLC applications. Thin-layer chromatography (TLC) was performed on F254 (Merck) and RP-18 F254 (Merck) precoated aluminum sheets. GC-MS analysis was performed by a Shimadzu GCMS QP 2010 plus instrument with Rtx-CLP2 cat-42302 apolar column (20 m-0.18 mm ID-0.14 $\mu \mathrm{m}$ df). The sugars for GC-MS analysis were purchased from Sigma. A class II laminar flow cabinet (Thermo Scientific, Germany) inverted microscope (Olympus, Japan), a $\mathrm{CO}_{2}$ incubator, a 96 well spectrophotometer (Thermo Scientific, Germany) and a Nuve centrifuge (Turkey) were used in biological activity tests.

\subsection{Plant Material}

Cephalaria anatolica Shkhiyan. was collected from between Tortum-Uzundere highway near Erzurum at about $1050 \mathrm{~m}$ height in 2013, and identified by Prof. Dr. H. Sumbul and Prof. Dr. R.S. Gokturk (Department of Biology, Faculty of Art and Science, Akdeniz University). A voucher specimen (R.S. Gokturk 7675) has been deposited at the Herbarium Research and Application Centre of Akdeniz University, Antalya in Turkey.

\subsection{Extraction and Isolation}

Dried and powdered aerial parts of $C$. anatolica $(2.8 \mathrm{~kg})$ were extracted with $\mathrm{MeOH}(5 \times 5 \mathrm{~L})$ at room temperature for overnight. Then methanolic solution was concentrated under the vacuum at $\sim 40$ ${ }^{\circ} \mathrm{C}$. The residue $(425.9 \mathrm{~g})$ was then extracted with $n-\mathrm{BuOH}: \mathrm{H}_{2} \mathrm{O}(1: 1,8 \times 150 \mathrm{~mL})$ solvent system. After the separation of $n$ - $\mathrm{BuOH}$ and $\mathrm{H}_{2} \mathrm{O}$ phases, the dried $n$ - $\mathrm{BuOH}$ fraction was extracted with $n$-hexane (15 $\times 100 \mathrm{~mL})$ to remove the apolar, oily and chlorophyll parts. The $n$-BuOH extract $(100 \mathrm{~g})$ was subjected to reversed-phase vacuum liquid chromatography (RP-VLC) with gradient $\mathrm{MeOH}: \mathrm{H}_{2} \mathrm{O}(0: 100 \rightarrow 100: 0$ 
$\%$ ) and to give 11 main fractions. The saponin-rich fractions 50\%, 40\% and 30\% $\mathrm{MeOH}$ were combined $(21.2 \mathrm{~g})$ and pre-isolated on MPLC using silica gel and suitable programme $(26 \times 920 \mathrm{~mm}$ Buchi glass column, flow rate: $25 \mathrm{~mL} / \mathrm{min}$., max. pressure: 40 bar) with eluting $\mathrm{CHCl}_{3}: \mathrm{MeOH}: \mathrm{H}_{2} \mathrm{O}(90: 10: 1 \rightarrow$ 61:32:7) solvent systems. Fractions 9,10 and 11 of MPLC (8.03 g) application were combined and loaded into an open column chromatography (CC) with solvent systems $\mathrm{CHCl}_{3}: \mathrm{MeOH}: \mathrm{H}_{2} \mathrm{O}(90: 10: 1 \rightarrow$ 61:32:7) yielded to $28 \mathrm{sub}$-fractions. The new compound $\mathbf{1}(10 \mathrm{mg})$, known compounds $\mathbf{5}(1.4 \mathrm{~g})$ and $\mathbf{1 1}$ $(90.7 \mathrm{mg})$ were obtained from $26^{\text {th }}, 18^{\text {th }}$ and $14^{\text {th }}$ sub-fractions of this column, respectively. Compound 6 $(6 \mathrm{mg})$ was yielded from the combination of the sub-fractions 12 and $13(150.8 \mathrm{mg})$ by silica gel CC using the solvent system $\mathrm{CHCl}_{3}: \mathrm{MeOH}: \mathrm{H}_{2} \mathrm{O}$ (80:20:2). Sub-fractions 21 and 22 were combined and exposed to another silica gel CC with a solvent system $\mathrm{CHCl}_{3}: \mathrm{MeOH}: \mathrm{H}_{2} \mathrm{O}$ (70:30:3) giving compound $8(101.1 \mathrm{mg})$, and the new compound $2(13.8 \mathrm{mg}) .23^{\text {rd }}$ fraction of the same column $(255.1 \mathrm{mg})$ was chromatographed on a RP-18 CC with $\mathrm{H}_{2} \mathrm{O}: \mathrm{MeOH}(1: 1)$ solvent system to give 4 different fractions. The fourth fraction (180.4 mg) was eluted with $\mathrm{CHCl}_{3}: \mathrm{MeOH}: \mathrm{H}_{2} \mathrm{O}(80: 20: 2)$ solvent system to yield compound $3(153.0 \mathrm{mg})$. The mixture of the sub-fractions $27^{\text {th }}$ and $28^{\text {th }}(459.9 \mathrm{mg})$ were loaded into CC afforded the new compound $\mathbf{1}(29.5 \mathrm{mg})$, compound $\mathbf{9}(33.7 \mathrm{mg})$ and compound $\mathbf{1 3}(14.0 \mathrm{mg})$ with the gradient of the solvent systems $\mathrm{CHCl}_{3}: \mathrm{MeOH}: \mathrm{H}_{2} \mathrm{O},(80: 20: 2 \rightarrow 65.5: 31: 5)$. Seventh sub-fraction $(1.4 \mathrm{~g})$ of MPLC application firstly was loaded in RP-18 CC to obtain 5 fractions. The last fraction $(480.8 \mathrm{mg})$ of this column was subjected to silica gel CC with $\mathrm{CHCl}_{3}: \mathrm{MeOH}: \mathrm{H}_{2} \mathrm{O}(70: 30: 3 \rightarrow 61: 32: 7)$ to give known compounds $10(90 \mathrm{mg})$ and $\mathbf{1 2}(120 \mathrm{mg})$. Combined $8^{\text {th }}$ and $9^{\text {th }}(10.1 \mathrm{~g})$ fractions of RP-VLC was subjected to another RP-VLC employing to $\mathrm{H}_{2} \mathrm{O}: \mathrm{MeOH}$ solvent system using different gradients $\mathrm{H}_{2} \mathrm{O}: \mathrm{MeOH}:(8: 1 \rightarrow 1: 1)$ to give 34 fractions. Fraction $31(1.5 \mathrm{~g})$ of this RP-VLC was loaded into silica gel CC with $\mathrm{CHCl}_{3}: \mathrm{MeOH}: \mathrm{H}_{2} \mathrm{O}(90: 10: 1 \rightarrow 85: 15: 1.5)$ solvent system to afford compounds 7 (54.2 mg) and 4 (80.0 $\mathrm{mg})$.

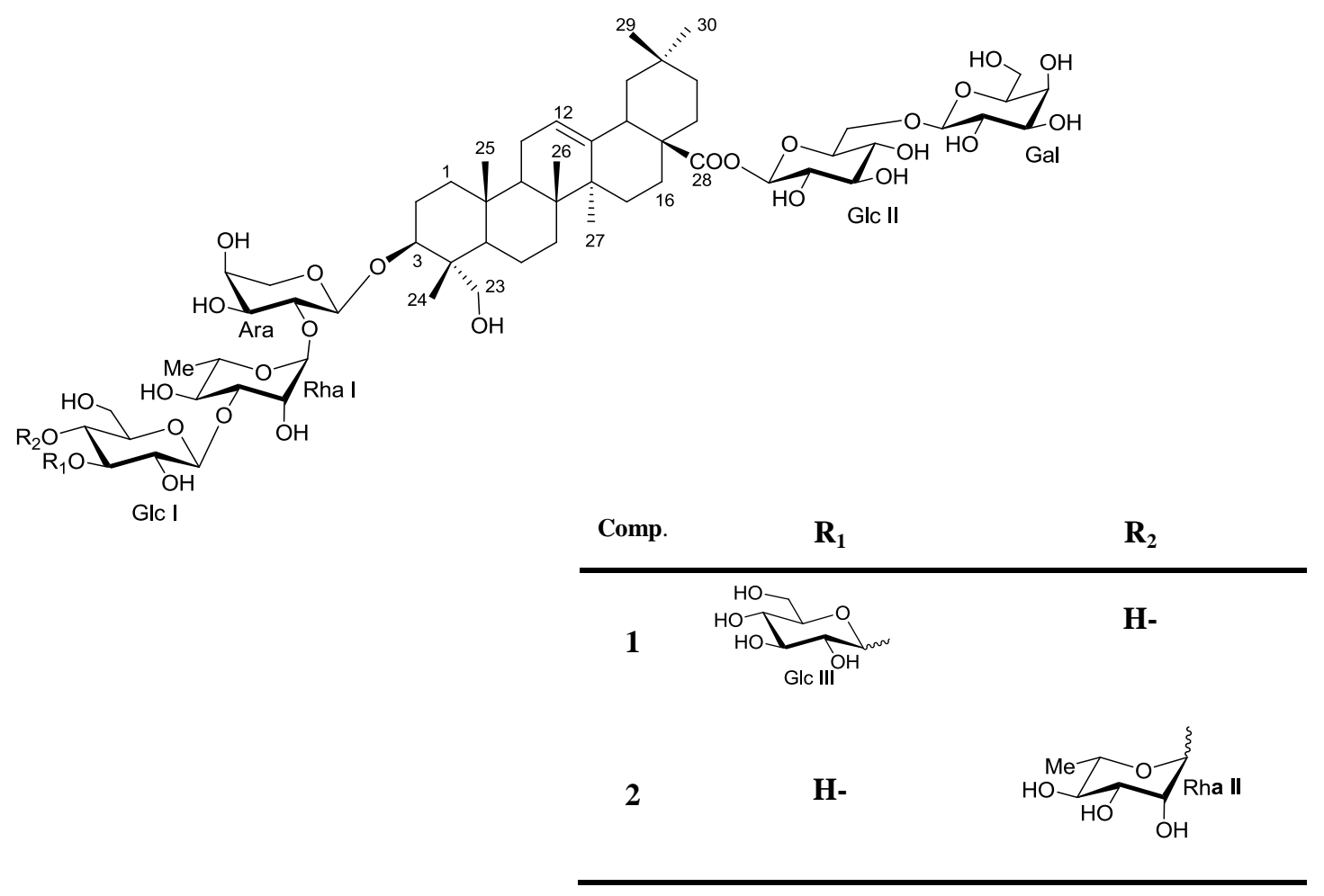

Figure 1. Structures of compounds 1-2. 
Table 1. ${ }^{1} \mathrm{H}$ NMR data for compounds $1-2^{a-b}$.

\begin{tabular}{|c|c|c|}
\hline Position & 1 & 2 \\
\hline 3 & $3.46, \mathrm{~m}$ & $3.47, \mathrm{~m}$ \\
\hline 5 & $1.20, \mathrm{~m}$ & $1.17, \mathrm{~m}$ \\
\hline 9 & $1.46, \mathrm{~m}$ & $1.50, \mathrm{~m}$ \\
\hline 12 & 5.13 , brs & 5.16 , brs \\
\hline 23 & $3.07,3.32, \mathrm{~m}$ & $3.08,3.32, \mathrm{~m}$ \\
\hline 24 & $0.54, \mathrm{~s}$ & $0.57, \mathrm{~s}$ \\
\hline 25 & $0.84, \mathrm{~s}$ & $0.86, \mathrm{~s}$ \\
\hline 26 & $0.65, \mathrm{~s}$ & $0.68, \mathrm{~s}$ \\
\hline 27 & $1.05, \mathrm{~s}$ & $1.09, \mathrm{~s}$ \\
\hline 29 & $0.84, \mathrm{~s}$ & $0.87, \mathrm{~s}$ \\
\hline \multirow[t]{2}{*}{30} & $0.83, \mathrm{~s}$ & $0.85, \mathrm{~s}$ \\
\hline & Ara at C-3 & Ara at C-3 \\
\hline 1 & $4.29, \mathrm{~d}(4.8)$ & $4.32, \mathrm{~d}(5.4)$ \\
\hline 2 & $3.49, \mathrm{~m}$ & $3.48, \mathrm{~m}$ \\
\hline 3 & $3.48, \mathrm{~m}$ & $3.46, \mathrm{~m}$ \\
\hline 4 & $3.56, \mathrm{~m}$ & $3.54, \mathrm{~m}$ \\
\hline 5 & $\begin{array}{l}3.29,3.62, \mathrm{~m} \\
\text { Rha }\end{array}$ & $\begin{array}{l}3.29,3.64, \mathrm{~m} \\
\text { Rha I }\end{array}$ \\
\hline 1 & 5.09, brs & 5.16 , brs \\
\hline 2 & $3.89, \mathrm{~m}$ & $3.92, \mathrm{~m}$ \\
\hline 3 & $3.60, \mathrm{~m}$ & $3.59, \mathrm{~m}$ \\
\hline 4 & $3.38, \mathrm{~m}$ & $3.37, \mathrm{~m}$ \\
\hline 5 & $3.76, \mathrm{~m}$ & $3.77, \mathrm{~m}$ \\
\hline 6 & $\begin{array}{l}\text { 1.07, d (6.0) } \\
\text { Glc I }\end{array}$ & $\begin{array}{l}\text { 1.08, d (6.6) } \\
\text { Glc I }\end{array}$ \\
\hline 1 & $4.37, \mathrm{~d}(7.8)$ & $4.35, \mathrm{~d}(7.8)$ \\
\hline 2 & $3.30, \mathrm{~m}$ & $3.15, \mathrm{~m}$ \\
\hline 3 & $3.31, \mathrm{~m}$ & $3.08, \mathrm{~m}$ \\
\hline 4 & $3.20, \mathrm{~m}$ & $3.36, \mathrm{~m}$ \\
\hline 5 & $3.13, \mathrm{~m}$ & $3.15, \mathrm{~m}$ \\
\hline 6 & $\begin{array}{l}3.64,3.70 \mathrm{~m} \\
\text { Glc II }\end{array}$ & $\begin{array}{l}3.40,3.58 \mathrm{~m} \\
\text { Rha II }\end{array}$ \\
\hline 1 & $4.24, \mathrm{~d}(7.2)$ & 5.03, brs \\
\hline 2 & $2.97, \mathrm{~m}$ & $3.66, \mathrm{~m}$ \\
\hline 3 & $3.16, \mathrm{~m}$ & $3.16, \mathrm{~m}$ \\
\hline 4 & $3.11, \mathrm{~m}$ & $3.46, \mathrm{~m}$ \\
\hline 5 & $3.19, \mathrm{~m}$ & $3.86, \mathrm{~m}$ \\
\hline \multirow[t]{2}{*}{6} & $3.41,3.68$ & $1.06, \mathrm{~d}(6.6)$ \\
\hline & Glc III at C-28 & Glc II at C-28 \\
\hline 1 & $5.20, \mathrm{~d}(7.2)$ & $5.30, \mathrm{~d}(7.8)$ \\
\hline 2 & $3.07, \mathrm{~m}$ & $3.07, \mathrm{~m}$ \\
\hline 3 & $3.26, \mathrm{~m}$ & $3.30, \mathrm{~m}$ \\
\hline 4 & $3.05, \mathrm{~m}$ & $3.08, \mathrm{~m}$ \\
\hline 5 & $3.30, \mathrm{~m}$ & $3.20, \mathrm{~m}$ \\
\hline 6 & $\begin{array}{l}3.50,3.92, \mathrm{~m} \\
\text { Gal }\end{array}$ & $\begin{array}{l}3.51,3.91, \mathrm{~m} \\
\text { Gal }\end{array}$ \\
\hline 1 & $4.43, \mathrm{~d}(7.8)$ & $4.47, \mathrm{~d}(7.8)$ \\
\hline 2 & $3.78, \mathrm{~m}$ & $3.78, \mathrm{~m}$ \\
\hline 3 & $3.10, \mathrm{~m}$ & $3.08, \mathrm{~m}$ \\
\hline 4 & $3.26, \mathrm{~m}$ & $3.25, \mathrm{~m}$ \\
\hline 5 & $3.42, \mathrm{~m}$ & $3.42, \mathrm{~m}$ \\
\hline 6 & $3.40,3.59 \mathrm{~m}$ & $3.46,3.63 \mathrm{~m}$ \\
\hline
\end{tabular}

${ }^{a 1} \mathrm{H} \mathrm{NMR}$ data $(\delta)$ were measured in DMSO $-d_{6}$ at $600 \mathrm{MHz}$.

${ }^{b}$ Coupling constants $(J)$ in $\mathrm{Hz}$ are given in parentheses . 
Table 2. ${ }^{13} \mathrm{C}$ NMR data for compounds $\mathbf{1 - 2}{ }^{a-b}$.

\begin{tabular}{|c|c|c|c|c|c|}
\hline & 1 & 2 & & 1 & 2 \\
\hline \multirow[t]{2}{*}{ Position } & \multicolumn{2}{|c|}{ Aglycon } & \multirow[t]{2}{*}{ Position } & \multicolumn{2}{|c|}{ Sugars } \\
\hline & & & & Ara at C-3 & Ara at C-3 \\
\hline 1 & 38.7 & 38.3 & 1 & 103.7 & 103.3 \\
\hline 2 & 25.8 & 25.5 & 2 & 74.4 & 74.0 \\
\hline 3 & 79.9 & 79.4 & 3 & 73.6 & 73.2 \\
\hline 4 & 42.7 & 42.2 & 4 & 68.6 & 68.2 \\
\hline 5 & 46.6 & 46.2 & 5 & 65.4 & 65.0 \\
\hline 6 & 17.5 & 17.1 & & Rha & Rha I \\
\hline 7 & 32.2 & 31.8 & 1 & 100.3 & 100.4 \\
\hline 8 & 39.3 & 38.9 & 2 & 69.8 & 69.2 \\
\hline 9 & 47.6 & 47.2 & 3 & 82.2 & 81.5 \\
\hline 10 & 36.4 & 35.9 & 4 & 71.3 & 70.7 \\
\hline 11 & 23.4 & 23.2 & 5 & 68.3 & 67.8 \\
\hline 12 & 122.1 & 121.6 & 6 & 18.2 & 17.8 \\
\hline 13 & 144.0 & 143.5 & & Gle I & Glc I \\
\hline 14 & 41.8 & 41.3 & 1 & 104.9 & 104.2 \\
\hline 15 & 27.7 & 27.3 & 2 & 75.0 & 74.4 \\
\hline 16 & 23.0 & 22.9 & 3 & 80.7 & 76.7 \\
\hline 17 & 46.0 & 45.9 & 4 & 69.5 & 80.7 \\
\hline 18 & 41.2 & 40.7 & $\begin{array}{l}5 \\
6\end{array}$ & $\begin{array}{l}76.8 \\
60.7\end{array}$ & $\begin{array}{l}76.6 \\
61.3\end{array}$ \\
\hline 19 & 46.4 & 45.5 & & Glc II & Rha II \\
\hline 20 & 30.7 & 30.3 & 1 & 103.6 & 99.8 \\
\hline 21 & 33.7 & 33.2 & 2 & 73.7 & 70.6 \\
\hline 22 & 32.0 & 31.6 & 3 & 77.3 & 72.1 \\
\hline 23 & 62.8 & 62.3 & 4 & 71.1 & 70.5 \\
\hline 24 & 13.5 & 13.0 & 5 & 76.9 & 68.1 \\
\hline 25 & 16.1 & 15.6 & 6 & 61.5 & 17.9 \\
\hline 26 & 17.1 & 16.7 & & $\begin{array}{l}\text { Glc III at } \\
\quad \text { C-28 }\end{array}$ & $\begin{array}{c}\text { Glc II at } \\
\text { C-28 }\end{array}$ \\
\hline 27 & 25.9 & 25.6 & 1 & 94.6 & 94.1 \\
\hline 28 & 175.7 & 175.3 & 2 & 74.1 & 74.7 \\
\hline 29 & 33.2 & 32.7 & 3 & 75.2 & 76.4 \\
\hline 30 & 23.8 & 23.4 & 4 & 70.5 & 70.6 \\
\hline & & & $\begin{array}{l}5 \\
6 \\
1 \\
2 \\
3 \\
4 \\
5 \\
6\end{array}$ & $\begin{array}{c}76.8 \\
68.5 \\
\text { Gal } \\
101.6 \\
71.7 \\
72.8 \\
67.8 \\
74.8 \\
61.7\end{array}$ & $\begin{array}{c}76.6 \\
68.0 \\
\text { Gal } \\
101.2 \\
71.2 \\
72.3 \\
67.4 \\
74.7 \\
60.8\end{array}$ \\
\hline
\end{tabular}

${ }^{a}{ }^{13} \mathrm{C}$ NMR data $(\delta)$ were measured in DMSO- $d_{6}$ at $150 \mathrm{MHz}$.

${ }^{\boldsymbol{b}}$ The assignments are based on DEPT, COSY, TOCSY, HSQC and HMBC experiments. 


\subsection{Alkaline Hydrolysis of the New Compounds}

Pure compounds (1-2) (5 mg each) were refluxed with $5 \% \mathrm{KOH}$ in water at $95{ }^{\circ} \mathrm{C}$ for $5 \mathrm{~h} \mathrm{[10].}$ The mixture was neutralized by $5 \% \mathrm{HCl}$ in water solution, and concentrated under vacuum to dryness. Then this mixture was extracted with $n-\mathrm{BuOH}: \mathrm{H}_{2} \mathrm{O}(1: 1)$ solvent system. The $n$ - $\mathrm{BuOH}$ layers gave prosapogenin 1a-2a. These prosapogenins were analyzed using ${ }^{1} \mathrm{H}$ NMR and HRESIMS methods and the results were used for the exact decision of the structures. While alkaline hydrolysis of $\mathbf{1}$ afforded prosapogenin 1a, which is a new compound according to our literature findings, compound $\mathbf{2}$ gave davisianoside B (4) [15] which was also afforded as a known triterpene glycoside, in this study.

3- $O$ - $\beta$-D-glucopyranosyl-(1 $\rightarrow 3$ )- $\beta$-D-glucopyranosyl-(1 $\rightarrow 3)$ - $\alpha$-L-rhamnopyranosyl-(1 $\rightarrow 2)$ - $\alpha$ L-arabinopyranosyl hederagenin (Prosapogenin 1a): A white, amorphous powder $(2 \mathrm{mg}) ;{ }^{1} \mathrm{H}$ NMR (DMSO- $\left.d_{6}, 600 \mathrm{MHz}\right)$; sugars: $\delta_{\mathrm{H}} 5.11(1 \mathrm{H}, \mathrm{br} \mathrm{s}, \mathrm{H}-1$ of Rha), $4.37(1 \mathrm{H}, \mathrm{d}, J=7.8 \mathrm{~Hz}, \mathrm{H}-1$ of Glc I), $4.29(1 \mathrm{H}, \mathrm{d}, J=6.0 \mathrm{~Hz}, \mathrm{H}-1$ of Ara); $4.24(1 \mathrm{H}, \mathrm{d}, J=7.2 \mathrm{~Hz}, \mathrm{H}-1$ of Glc II $)$; positive-ion HRESIMS $\mathrm{m} / z$ $1097.5487[\mathrm{M}+\mathrm{Na}]^{+}$(calcd for $\mathrm{C}_{53} \mathrm{H}_{86} \mathrm{O}_{22} \mathrm{Na}, 1097.5503$ ) (see Supporting Information).

\subsection{Acidic Hydrolysis and GC-MS Analysis of the New Compounds}

The identification of the monosaccharide units of the glycosides was performed by GC-MS analysis with authentic samples [9]. Each compound $(\sim 5 \mathrm{mg})$ was hydrolyzed with $1 \mathrm{~N} \mathrm{HCl}(2 \mathrm{~mL})$ for $6 \mathrm{~h}$ at $90{ }^{\circ} \mathrm{C}$. After extraction with $\mathrm{CHCl}_{3}(3 \times 5 \mathrm{~mL})$, the aqueous layer was evaporated to dryness and kept under hi-vac for $24 \mathrm{~h}$. Furthermore, the residue of monosaccharides was dissolved in anhydrous pyridine $(1 \mathrm{~mL}$ ), and then $1 \mathrm{~mL}$ of HMDS-TMCS (hexamethyldisilazane-trimethylchlorosilane, 3:1) was added, and the mixture was stirred at $70{ }^{\circ} \mathrm{C}$ for $1 \mathrm{~h}$. The mixture was concentrated under a $\mathrm{N}_{2}$ stream and dissolved in $n$-hexane for GC-MS analyses. Similarly, a mixture containing standard monosaccharide units was silylated by the same procedure. The retention times of the standard monosaccharides L-arabinose, L-rhamnose, D-mannose, D-xylose, D-galactose and D-glucose were found to be 5.33, 5.42, 5.86, 6.32, 7.75 and $8.10 \mathrm{~min}$, respectively. The monosaccharide moieties of the samples were determined as L-arabinose, L-rhamnose, D-galactose and D-glucose giving the peaks at 5.33, 5.42, 7.74 and 8.09 min for $\mathbf{1}$ and 5.33, 5.42, 7.74 and 8.10 min for $\mathbf{2}$, respectively.

3-O- $\beta$-D-glucopyranosyl-( $1 \rightarrow 3)$ - $\beta$-D-glucopyranosyl- $(1 \rightarrow 3)$ - $\alpha$-L-rhamnopyranosyl- $(1 \rightarrow 2)-\alpha$ $L$-arabinopyranosyl hederagenin 28-O- $\beta$-D-galactopyranosyl- $(1 \rightarrow 6)-\beta$-D-glucopyranosyl ester $(\mathbf{1})$

A light brown, amorphous powder $(39.5 \mathrm{mg}) ;[\alpha]_{\mathrm{D}}^{25}-3.85(c$ 2.6, MeOH$) ; 98.26 \%$ purity; IR (KBr) $v_{\max } 2958,2927,2871,1729,1464,1380,1275,1123,1073,749 \mathrm{~cm}^{-1}$; ${ }^{1} \mathrm{H}$ NMR (DMSO- $d_{6}, 600$ $\mathrm{MHz}$ ) and ${ }^{13} \mathrm{C}$ NMR (DMSO- $d_{6}, 150 \mathrm{MHz}$ ): see Tables 1 and 2, respectively; positive-ion HRESIMS $m / z 1421.6518[\mathrm{M}+\mathrm{Na}]^{+}$(calcd for $\mathrm{C}_{65} \mathrm{H}_{106} \mathrm{O}_{32} \mathrm{Na}, 1421.6559$ ).

3-O- $\alpha$-L-rhamnopyranosyl-( $1 \rightarrow 4)$ - $\beta$-D-glucopyranosyl- $(1 \rightarrow 3)$ - $\alpha$-L-rhamnopyranosyl- $(1 \rightarrow 2)$ $\alpha$-L-arabinopyranosyl hederagenin 28-O- $\beta$-D-galactopyranosyl- $(1 \rightarrow 6)-\beta$-D-glucopyranosyl ester $(2) \mathrm{A}$ light brown, amorphous powder $(13.8 \mathrm{mg}) ;[\alpha]_{\mathrm{D}}^{25}-14.29(c 1.4, \mathrm{MeOH}) ; 99.05 \%$ purity; IR $(\mathrm{KBr}) v_{\max }$ 2918, 2849, 1731, 1463, 1381, 1276, 1261, 1073, $753 \mathrm{~cm}^{-1} ;{ }^{1} \mathrm{H}$ NMR (DMSO- $d_{6}, 600 \mathrm{MHz}$ ) and ${ }^{13} \mathrm{C}$ NMR (DMSO- $d_{6}, 150 \mathrm{MHz}$ ): see Tables 1 and 2, respectively; positive-ion HRESIMS $\mathrm{m} / \mathrm{z} 1405.6568$ $[\mathrm{M}+\mathrm{Na}]^{+}$(calcd for $\left.\mathrm{C}_{65} \mathrm{H}_{106} \mathrm{O}_{31} \mathrm{Na}, 1405.6610\right)$.

\subsection{In vitro Bioactivity Assay}

\subsubsection{Hemolytic Activity Assay}

Hemolytic activity of the molecules was measured according to Nalbantsoy et al. (2011) [20] with some modifications. Red blood cells were obtained from healthy human volunteers. Blood was 
collected with BD Vacutainer TM (NH 143 I. U., Belliver Industrial Estate, Plymouth, UK). An amount of $7 \mathrm{~mL}$ of blood was washed three times using a sterile saline solution $(0.89 \%$, w/v NaCl, pyrogen free) and then it was centrifuged at 2000/5 $\mathrm{g}$. The final cell suspension was prepared by diluting the pellet to $0.5 \%$ using saline solution. A volume of $0.01 \mathrm{~mL}$ of the cell suspension was mixed in $\mathrm{U}$ button 96-well microplate with $0.05 \mathrm{~mL}$ diluents containing 125,250 and $500 \mu \mathrm{g} / \mathrm{mL}$ concentrations of molecules in saline solutions. QS-21 was used as a control saponin compound. The mixtures were incubated for $30 \mathrm{~min}$ at $37{ }^{\circ} \mathrm{C}$ and centrifuged at $800 / 10 \mathrm{~g}$. The free hemoglobin in the supernatants was measured spectrophotometrically at $412 \mathrm{~nm}$. Saline solution and distilled water were used as minimal and maximal hemolytic controls. The hemolytic percent was developed by the saline control, subtracted from all groups. Each experiment was included triplicates at each concentration. The data were expressed as mean \pm standard deviation (S.D.) and examined for their statistical significance of difference with Student t-test, ANOVA and the post hoc test (dunnet referring to homogeneity and normality of the absorbance using SPSS 16.0). P-values of less than $0.05,0.01$ and 0.001 were considered to be statistically significant.

\subsubsection{Immunomodulatory Assay: Measurement of the Effects on Cytokine Production}

Heparinized peripheral human whole blood obtained from healthy volunteers were stimulated with 50 ng PMA (Sigma, St. Lois, MO, U.S.A.) plus 400 ng ionomycin (Sigma, St. Lois, MO, U.S.A.) for IL-2, IFN- $\gamma$ and IL-1 $\beta$ and incubated in the presence of test samples or reference compound QS-21 for $48 \mathrm{~h}$. The cultured supernatants were collected and the concentration of the cytokines produced by macrophages or lymphocytes was measured using a commercially available enzyme-linked immunosorbent assay (ELISA) (Vienne, Austria). The assays were performed according to the manufacturer's recommendations. The average absorbance readings of the samples were then compared with the concentrations of the standard curve, and the samples concentrations of each cytokine were calculated. The results of IL-2, IFN- $\gamma$ and IL- $1 \beta$ were expressed as picograms per milliliter. The minimum detection limits were $9.1 \mathrm{pg} / \mathrm{mL}, 0.99 \mathrm{pg} / \mathrm{mL}$, and $0.3 \mathrm{pg} / \mathrm{mL}$ for IL-2, IFN- $\gamma$ and IL- $1 \beta$, respectively. Diluted supernatants were used for all assays and each assay was performed in triplicate.

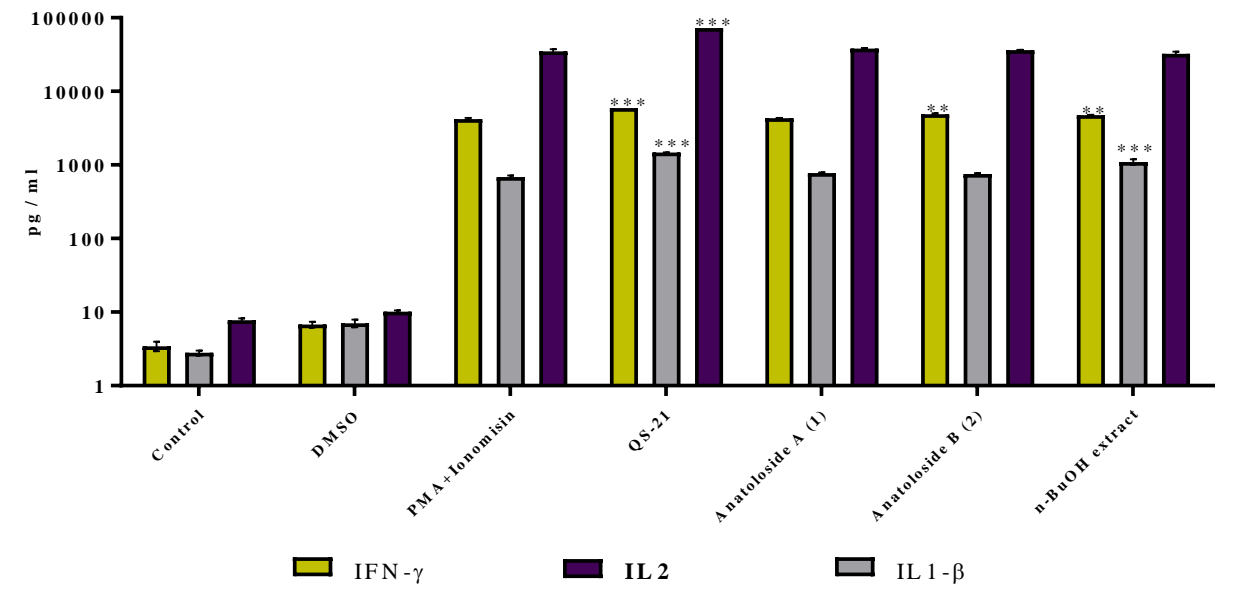

Figure 2. Immunomodulatory activities of $n$-butanol extract and cephosides B-C (1-2) from C. anatolica

Human whole blood (containing $20 \mathrm{U} / \mathrm{mL}$ heparine) was suspended in RPMI-1640 medium supplemented with $\% 10 \mathrm{FBS}, 100 \mathrm{U} / \mathrm{mL}$ penicillin and $100 \mathrm{mg} / \mathrm{mL}$ streptomycin in a 1:10 ratio. PMA $(50 \mathrm{ng} / \mathrm{mL})$ and ionomycin $(400 \mathrm{ng} / \mathrm{mL})$ were added to the whole blood for stimulation of immune system cells. The samples were dissolved as stock solution in DMSO at concentration of $5 \mathrm{mg} / \mathrm{mL}$ and 
DMSO was used as negative control. An amount of $1 \mathrm{~mL}$ of the heparinized blood which was stimulated by PMA $(50 \mathrm{ng} / \mathrm{mL})$ and ionomycin $(400 \mathrm{ng} / \mathrm{mL})$ was transferred into each well of 24 -well plate and incubated at $37^{\circ} \mathrm{C}$ for 48 in the absence or presence of $3 \mu \mathrm{g} / \mathrm{mL}$ concentrations of samples or QS-21 as the reference compound. The culture supernatants were then mixed with PBS/ $0.05 \%$ thiomersal at 1:2 ratio and were assayed using the specific ELISA method for IL-2, IFN- $\gamma$ and IL- $1 \beta$. The experimental protocol was described in a previous report [20-22]. The protocol was approved by the Human Ethics Committee of Ege University, and all of the procedures used conformed to the declaration of Helsinki. The subjects were informed about the procedures and signed the informed consent forms (approval number: E.215344).

\section{Results and Discussion}

\subsection{Structure Elucidation}

Cephoside B (1) was isolated as a light brown, amorphous solid. Its molecular formula was determined as $\mathrm{C}_{65} \mathrm{H}_{106} \mathrm{O}_{32}$ by HRESIMS at $m / z 1421.6518[\mathrm{M}+\mathrm{Na}]^{+}$(calcd for $\mathrm{C}_{65} \mathrm{H}_{106} \mathrm{O}_{32} \mathrm{Na}$, 1421.6559), with 1 degree of unsaturation. The IR spectrum showed absorption bands at 1729, 1464, $1380,1073 \mathrm{~cm}^{-1}$ corresponding carbonyl, olefin and etheric functionalities, respectively. The ${ }^{1} \mathrm{H}$ NMR spectrum (see Table 1) displayed six tertiary methyl signals at $\delta_{\mathrm{H}} 0.54(\mathrm{H}-24), 0.84(\mathrm{H}-25), 0.65(\mathrm{H}-26)$, $1.05(\mathrm{H}-27), 0.84(\mathrm{H}-29), 0.83(\mathrm{H}-30)$, (each $3 \mathrm{H}, \mathrm{s})$, an olefinic proton signal at $\delta_{\mathrm{H}} 5.13(1 \mathrm{H}, \mathrm{br} \mathrm{s}, \mathrm{H}-$ $12)$, an oxygen-bearing methine proton at $\delta_{\mathrm{H}} 3.46(1 \mathrm{H}, \mathrm{m}, \mathrm{H}-3)$ and one primary alcoholic function at $\delta_{\mathrm{H}}$ 3.07 and $3.32(2 \mathrm{H}, \mathrm{m}, \mathrm{H}-23)$. The ${ }^{13} \mathrm{C}$ NMR (see Table 2 ) and HSQC spectra established the presence of 65 carbon signals, of which 30 were assigned to the aglycone moiety, comprising six methyl, eleven methylene (one oxygenated), five methine (one oxygenated and one double bond), and eight quaternary carbons (one carbonyl) and 35 to a sugar portion made up of six sugar units. The carbon resonances in the ${ }^{13} \mathrm{C}$ NMR spectrum, for tertiary six methyl carbons at $\delta_{\mathrm{C}} 13.5$ (C-24), 16.1 (C-25), 17.1 (C-26), 25.9 (C-27), 33.2 (C-29), 23.8 (C-30), two olefinic carbons at $\delta_{\mathrm{C}}$ 122.1, 144.0, the oxygen-bearing methine carbon at $\delta_{\mathrm{C}} 79.9(\mathrm{C}-3)$ and the primary alcoholic carbon at $\delta_{\mathrm{C}} 62.8$ suggested that compound 1 possessed hederagenin as an aglycone [23]. Analysis of the 1D and 2D NMR spectral data (including ${ }^{1} \mathrm{H}-{ }^{1} \mathrm{H}$ COSY, HSQC, HMBC) allowed for the establishment of the structure of $\mathbf{1}$. Its HSQC spectrum permitted the assignment of all the protons to their bonding carbons. The downfield shifts of C-3 (79.9) and C-28 (175.7) of the aglycone indicated that compound 1 is a bisdesmosidic glycoside. The ${ }^{1} \mathrm{H}$ NMR spectrum displayed in the sugar region signals corresponding to six anomeric protons at $\delta_{\mathrm{H}} 4.29$ (d, $J=4.8 \mathrm{~Hz}$, Ara), 5.09 (br s, Rha), 4.37 (d, $J=7.8 \mathrm{~Hz}, \mathrm{Glc}$ I), 4.24 (d, $J=7.2 \mathrm{~Hz}$, Glc II), $5.20(\mathrm{~d}, J=7.2 \mathrm{~Hz}$, Glc III) and $4.43(\mathrm{~d}, J=7.8 \mathrm{~Hz}, \mathrm{Gal})$ which were unambiguously correlated by HSQC experiment to the corresponding carbon resonances at $\delta_{\mathrm{C}} 103.7,100.3,104.9,103.6,94.6$, and 101.6 indicated the presence of six sugar moieties, respectively. The coupling constants showed two $\beta$ glycosidic linkages for three glucose units and one galactose unit and two $\alpha$-glycosidic linkages for one rhamnose and one arabinose units. This fact also confirmed by way of acidic hydrolysis and GC-MS analysis. Analysis of the HMBC spectrum then enabled the connectivity of these spin coupling fragments and the other functional groups. The HMBC correlations between $\mathrm{H}-1$ of arabinose at $\delta_{\mathrm{H}} 4.29$ and C-3 of aglycone at $\delta_{\mathrm{C}} 79.9$ and between $\mathrm{H}-1$ of glucose III at $\delta_{\mathrm{H}} 5.20$ and carbonyl carbon at $\delta_{\mathrm{C}}$ 175.7 indicated that the glycosidic chains were located at C-3 and C-28 of aglycone, respectively. The other $\mathrm{HMBC}$ correlations between $\mathrm{H}-1$ of rhamnose at $\delta_{\mathrm{H}} 5.09$ and C-2 of arabinose at $\delta_{\mathrm{C}} 74.4$, between $\mathrm{H}-1$ of glucose I at $\delta_{\mathrm{H}} 4.37$ and C-3 of rhamnose at $\delta_{\mathrm{C}} 82.2$, between $\mathrm{H}-1$ of glucose II at $\delta_{\mathrm{H}} 4.24$ and C3 of glucose I at $\delta_{\mathrm{C}} 80.7$ and between $\mathrm{H}-1$ of galactose at $\delta_{\mathrm{H}} 4.43$ and C-6 of glucose III at $\delta_{\mathrm{C}} 68.5$ proved all the linking points between sugar to sugar units. After the alkaline hydrolysis of $\mathbf{1}$, the ${ }^{1} \mathrm{H}$ NMR and HRESIMS data of prosapogenin 1a also confirmed the structure. The overall structure of compound 1 was thus determined as 3-O- $\beta$-D-glucopyranosyl-( $1 \rightarrow 3)$ - $\beta$-D-glucopyranosyl-( $1 \rightarrow 3)$ - $\alpha$ L-rhamnopyranosyl-( $1 \rightarrow 2)$ - $\alpha$-L-arabinopyranosyl hederagenin $28-\mathrm{O}-\beta$-D-galactopyranosyl-( $1 \rightarrow 6)-\beta$ D-glucopyranosyl ester namely cephoside B (1). 
Compound 2 was obtained as a light brown, amorphous powder with a molecular formula of $\mathrm{C}_{65} \mathrm{H}_{106} \mathrm{O}_{31}$, as determined by HRESIMS at $\mathrm{m} / z$ 1405.6568 $[\mathrm{M}+\mathrm{Na}]^{+}$(calcd for $\mathrm{C}_{65} \mathrm{H}_{106} \mathrm{O}_{31} \mathrm{Na}$, 1405.6610). Comparison of the ${ }^{1} \mathrm{H}$ and ${ }^{13} \mathrm{C}$ NMR data (see Tables 1 and 2) with those of compound $\mathbf{1}$, suggested that compound $\mathbf{2}$ had the same hederagenin aglycone [23]. 1D and 2D NMR data indicated that compound 2 possessed another rhamnose unit (Rha II) instead of one of the glucose (Glc II) moiety of compound 1. The sugar part of $\mathbf{2}$ was found to consist of two glucose units, two rhamnose units, one arabinose and one galactose units in a sugar part of the compound. The ${ }^{1} \mathrm{H}$ NMR chemical shift at $\delta_{\mathrm{H}}$ 4.32 (d, $J=5.4 \mathrm{~Hz}$, Ara), 5.16 (br s, Rha I), 4.35 (d, $J=7.8 \mathrm{~Hz}$, Glc I), 5.03 (br s, Rha II), 5.30 (d, $J=$ $7.8 \mathrm{~Hz}, \mathrm{Glc}$ II) and 4.47 (d, $J=7.8 \mathrm{~Hz}, \mathrm{Gal})$ are attributed to anomeric proton signals for the each sugar part of the compound. The anomeric carbons of the sugar units gave chemical shifts at $\delta_{\mathrm{C}} 103.3,100.4$, 104.2, 99.8, 94.1 and 101.2 in the ${ }^{13} \mathrm{C}$ NMR spectrum. The coupling constants confirmed the presence of $\beta$-glycosidic linkages for two glucoses, one galactose and $\alpha$-glycosidic linkage for one arabinose, two rhamnose units. Moreover, acid hydrolysis of compound 2 gave D-glucose, L-arabinose, L-rhamnose and D-galactose which were identified by GC-MS analysis using authentic samples for comparison [10]. The HMBC correlations were observed between anomeric proton signals and aglycone carbons at $\delta_{\mathrm{H}}$ 4.32 (Ara) and $\delta_{\mathrm{C}} 79.4$ (C-3 of aglycone), $\delta_{\mathrm{H}} 5.30$ (Glc II) and $\delta_{\mathrm{C}} 175.3$ (C-28 of aglycone) confirmed the linkage points of the sugar moieties to the aglycone. An exact determination of the sequence and linkages between carbohydrate moieties was also obtained from the HMBC spectrum (see Sup. Info.), which showed key correlation peaks between the protons and carbons $\delta_{\mathrm{H}} 5.16$ (Rha I) and $\delta_{\mathrm{C}} 74.0(\mathrm{C}-2$ of Ara), $\delta_{\mathrm{H}} 4.35$ (Glc I) and $\delta_{\mathrm{C}} 81.5$ (C-3 of Rha I), $\delta_{\mathrm{H}} 5.03$ (Rha II) and $\delta_{\mathrm{C}} 80.7$ (C-4 of Glc I), and $\delta_{\mathrm{H}}$ $4.47(\mathrm{Gal})$ and $\delta_{\mathrm{C}} 68.0$ (C-6 of Glc II), indicating the connection of the sugars to each other. On the basis of all this evidence, the exact structure of 2 was determined to be 3-O- $\alpha$-L-rhamnopyranosyl- $(1 \rightarrow$ 4)- $\beta$-D-glucopyranosyl-( $1 \rightarrow 3)$ - $\alpha$-L-rhamnopyranosyl-(1 $\rightarrow 2)$ - $\alpha$-L-arabinopyranosyl hederagenin 28 $\mathrm{O}-\beta$-D-galactopyranosyl-( $1 \rightarrow 6)-\beta$-D-glucopyranosyl ester namely cephoside $\mathrm{C}$.

\subsection{Hemolytic and Immunomodulatory Activities}

Table 3. Hemolytic activities of $n$-butanol extract and compounds 1-2 from Cephalaria anatolica $^{a-c}$.

\begin{tabular}{ccc}
\hline Group $(\boldsymbol{\mu g} / \mathbf{m L})$ & Absorbance value & Hemolytic percentage $(\%)$ \\
\hline Saline & $0.16 \pm 0.01$ & $0.00 \pm 0.60$ \\
\hline Distillated water & $1.14 \pm 0.04$ & $100.00 \pm 3.96^{* * * *}$ \\
\hline QS-21 & & $85.77 \pm 2.84^{* * * *}$ \\
\hline 500 & $1.00 \pm 0.03$ & $60.04 \pm 1.07^{* * * *}$ \\
250 & $0.75 \pm 0.01$ & $55.27 \pm 1.17^{* * *}$ \\
125 & $0.70 \pm 0.01$ & \\
\hline Cephoside B & & $-0.75 \pm 1.94$ \\
500 & $0.15 \pm 0.02$ & $-5.93 \pm 2.70$ \\
250 & $0.10 \pm 0.03$ & $-9.01 \pm 0.58$ \\
\hline Cephoside C & $0.07 \pm 0.01$ & $0.54 \pm 0.48$ \\
\hline 500 & & $-3.45 \pm 3.29$ \\
250 & $0.17 \pm 0.01$ & $-6.94 \pm 1.78$ \\
\hline 125 & $0.13 \pm 0.03$ & \\
\hline n-butanol Extract & $0.09 \pm 0.02$ & $-0.44 \pm 5.86$ \\
250 & & $-3.42 \pm 4.66$ \\
125 & $0.16 \pm 0.06$ & $-4.67 \pm 2.36$ \\
\hline
\end{tabular}

$a_{*} p<0.05 ; * * p<0.01 ; * * * p<0.001{ }^{b}$ Hemolytic percents of saline and distilled water were included as minimal and maximal hemolytic control. ${ }^{c}$ All values represent the mean \pm standard deviation $(\mathrm{n}=3$ test). 
The analyses of IL-1 $\beta$, IFN- $\gamma$ and IL-2 cytokine production in stimulated whole blood by activation with PMA plus ionomycin were determined by ELISA. Cytokines are proteins which represent a vital role in the human immune response. The utilities of cytokines are various and contain roles in normal T-cell-mediated immunity, the inflammatory response, autoimmunity, on cancer and allergy treatments [24]. Compared to the PMA plus ionomicin induced whole blood control group (4480.6 pg/mL), the results show that cephoside $\mathrm{C}$ and $n$-butanol extract enhanced considerable IFN $-\gamma$ secretion with values of 4874.11 and $4750.20 \mathrm{pg} / \mathrm{mL}$, respectively. Besides that, $n$-butanol extract of $C$. anatolica displayed a strong IL- $1 \beta$ secretion with value of $760.52 \mathrm{pg} / \mathrm{mL}$ which is closely linked to the innate immune response through inflammasome-driven host resistance with infection (PMA + ionomisin $=680.20 \mathrm{pg} / \mathrm{mL}$ ). None of the compounds changed IL-2 levels significantly (see Fig. 2). The two new triterpenoid saponins (cephosides $\mathrm{B}-\mathrm{C}, \mathbf{1 - 2}$ ) and the $n$-butanol extract were also evaluated for their hemolytic activity in human erythrocyte cells. According to the results, they didn't exhibit hemolytic activity considerably.

\section{Acknowledgments}

The authors gratefully acknowledge to Research Grant Office of Ege University (2016/Fen/037) for financial support and thank Prof. Dr. H. Sumbul and Prof. Dr. R. S. Gokturk for collection and identification of the plant. TUBITAK and EBILTEM are gratefully acknowledged for providing NMR (600 MHz), HRESIMS and NMR (400 MHz) spectra, respectively. They would like to thank Ege University, Center for Drug Research and Development and Pharmacokinetic Applications for GC-MS analysis. The authors also thank Assoc. Prof. Ayse NALBANTSOY for biological activity tests.

\section{Supporting Information}

Supporting Information accompanies this paper on http://www.acgpubs.org/RNP

\section{References}

[1] J. L. Reveal and M. W. Chase (2011). APG III: Bibliographical information and synonymy of Magnoliidae, Phytotaxa 19, 71-134.

[2] P. H. Davis (1972). Flora of Turkey and the East Aegean Islands, Edinburgh: University of Edinburgh Press; 4, 585-592.

[3] S. Basar, M. M. Karaoglu and H. Boz (2016). The effects of Cephalaria flour on the quality of sunn pest (Eurygaster Integriceps) damaged wheat. J. Food Quality 39, 13-24.

[4] F. Gunes and N. Ozhatay (2011). An ethnobotanical study from Kars (Eastern) Turkey, Biol. Divers. Conserv. 4, 30-41.

[5] K. Mustafayeva, V. Mahiou-Leddet, T. Suleymanov, Y. Kerimov, E. Ollivier and R. Elias (2011). Chemical constituents from the roots of Cephalaria kotschyi, Chem. Nat. Compd. 47, 839.

[6] I. S. Movsumov, E. A. Garaev and M. I. Isaev (2009). Flavonoids from Cephalaria grossheimii, Chem. Nat. Compd. 45, 422-423.

[7] N. Tabatadze, R. Elias, R. Faure, P. Gerkens, M. C. De Pauw-Gillet, E. Kemertelidze, A. Chea and E. Ollivier (2007). Cytotoxic triterpenoid saponins from the roots of Cephalaria gigantea, Chem. Pharm. Bull. 55, 102-105.

[8] N. B. Sarikahya and S. Kirmizigul (2012). Antimicrobially active hederagenin glycosides from Cephalaria elmaliensis, Planta Med. 78, 828-833.

[9] N. B. Sarikahya and S. Kirmizigul (2010). Antimicrobial triterpenoid glycosides from Cephalaria scoparia, J. Nat. Prod. 73, 825-830.

[10] N. B. Sarikahya (2014). Aristatosides A-C, hederagenin-type triterpene saponins from Cephalaria aristata, Phytochem Lett. 8, 149-155.

[11] D. Godjevac, V. Vajs, N. Menkovic, V. Tesevic, P. Janackovic and S. Milosavljevic (2004). Flavonoids from flowers of Cephalaria pastricensis and their antiradical activity, J. Serb. Chem. Soc. 69, 883-886. 
[12] S. Pasi, N. Aligiannis, H. Pratsinis, A-L Skaltsounis and L. B. Chinou. (2009). Biologically active triterpenoids from Cephalaria ambrosioides, Planta Med. 75, 163-167.

[13] P. Kayce and S. Kirmizigul (2017). Isolation and identification of a new saponin from Cephalaria aytachii, Nat. Prod. Res. 31, 50-57.

[14] V. R. Netala, S. B. Ghosh, P. Bobbu, D. Anitha and V. Tartte (2015). Triterpenoid saponins: A review on biosynthesis, applications and mechanisim of their action, Int. J. Pharm. Pharm. Sci. 1, 0975-1491.

[15] P. Kayce, N. B. Sarikahya and S. Kirmizigul (2014). Two novel saponins from Cephalaria davisiana (Dipsacaceae), Phytochem Lett. 10, 324-329.

[16] S. Saito, S. Sumita, N. Tamura, Y. Nagamura, K. Nishida, M. Ito and I. Ishiguro (1990). Saponins from the leaves of Aralia elata seem (Araliaceae), Chem. Pharm. Bull. 38, 411-414.

[17] Q. Mao, D. Cao and X. S. Jia (1993). Studies on the chemical constituents of Lonicera macranthoides, Acta. Pharm. Sin. 28, 273-281.

[18] M. M. Mukhamedziev, P. K. Alimbaeva, T. T. Gorovits and N. K. Abubakirov (1971). Structure of the triterpenoid glycoside from Dipsacus azureus dipsacoside B, Khim. Prir. Soedin. 7, 153-158.

[19] A. Braca, G. Autore, F. De Simone, S. Marzocco, I. Morelli, F. Venturella and N. De Tommasi (2004). Cytotoxic saponins from Schefflera rotundifolia, Planta Med. 70, 960-966.

[20] A. Nalbantsoy, T. Nesil, S. Erden, I. Calis and E. Bedir (2011). Adjuvant effects of Astragalus saponins macrophyllosaponin B and astragaloside VII, J. Ethnopharmacol. 134, 897-903.

[21] E. Yesilada, E. Bedir, I. Calis, Y. Takaishi and Y. Ohmoto (2005). Effects of triterpene saponins from Astragalus species on in vitro cytokine release, J. Ethnopharmacol. 96, 71-77.

[22] A. Lenarczyk, J. Helsloot, K. Farmer, L. Peters, A. Sturgess and B. Kirkham (2000). Antigen-induced IL-17 response in the peripheral blood mononuclear cells (PBMC) of healthy controls, Clin. Exp. Immunol. 122, 41-48.

[23] A. Sharma, S. C. Sati, O. P. Sati, M. D. Sati and S. K. Kothiyal (2013). Triterpenoid saponins from the pericarps of Sapindus mukorossi, HPC J. Chem. 2013, 1-5.

[24] L. Borish and L. Rosenwasser (1996). Update on cytokines, J. Allergy Clin. Immunol. 97, 719-730.

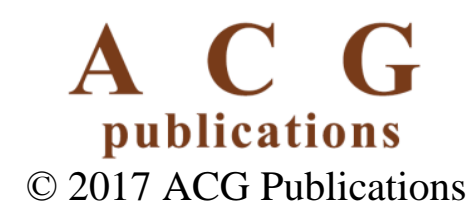

